УДК 611.126.3-018.1-019

DOI: $10.24061 / 1727-0847.17 .4 .2018 .4$

\title{
P.P. Симівська
}

Кафедра нормальної анатомії (зав. - проф. Л.Р. Матешук-Вацеба) Львівського начіонального медичного університету імені Данила Галицького

\section{МАКРО-, МІКРО- ТА УЛЬТРАСТРУКТУРНА ОРГАНІЗАЦІЯ ТРИСТУЛКОВОГО ТА ДВОСТУЛКОВОГО КЛАПАНІВ СЕРЦЯ БІЛОГО ЩУРА}

Резюме. У статті наведено та проаналізовано дослідження, що проводили на білих щурах самках та самцях репродуктивного віку. Метою дослідження було визначити особливості макро-, мікро- та ультраструктурної організації тристулкового та двостулкового клапанів серця експериментальних тварин. Встановлено, що ендокард правого та лівого передсердно-шлуночкових клапанів складається 3 трьох шарів: внутрішнього та зовнішнього - ендотеліального - у вигляді пласту плоских полігональних клітин з нерівними хвилястими краями, підендотеліального шару, який представлений сполучною тканиною та м'язово-еластичного шару, що містить гладкі міоцити, обплетені пучками колагенових волокон 3 фібробластами та більшою кількістю еластичних волокон. Електронно-мікроскопічне дослідження дво- та тристулкового клапанів серця показало, що товщина ендотеліальних клітин неоднакова в різних iï ділянках. Ендотелій розміщується на товстій базальній мембрані. Колагенові волокна побудовані 3 пучків фібрил, зцементованих глікозамінгліканами та глікопротеїнами. Еластичні волокна формуються з еластинових протофібрил, що в комплексі з глікопротеїнами утворюють мікрофібрили.

Ключові слова: структурна організація; тристулковий клапан; двостулковий клапан; білий щур.

За останні 10 років серцево-судинні захворювання стали основною причиною смертності у світі та становлять $30 \%$ усіх випадків і $45 \%$ від усіх неінфекційних причин смерті [1]. Патологія серцево-судинної системи є найбільш розповсюдженою, має тенденцію до збільшення, найчастіше призводить до інвалідності та смертності населення у працездатному віці та є медичною і соціальною проблемою [2]. Незважаючи на велику кількість морфологічних досліджень [3-5], багато питань, що стосуються клапанного апарату серця, залишаються не 3'ясованними. Клапанний апарат серця забезпечує нормальну гемодинаміку структури серцевого викиду і біомеханіку серця в цілому [6]. Ушкодження будь-якого із структурних компонентів передсердно-шлуночкового клапану призводить до появи патології клапанного апарату в цілому, що може призвести до порушень гемодинаміки $[7,8]$. Залишаються актуальними питання щодо динаміки розвитку клапанів та їх структурних компонентів [9-11], кровопостачання клапанного апарату в нормі [12], оскільки вони несуть велике функціональне навантаження.

Мета дослідження: встановити особливості макро-, мікро- та ультраструктурної організації тристулкового та двостулкового клапанів серця білого щура.
Матеріал і методи. Дослідження виконано на 24 статевозрілих білих шурах репродуктивного віку (12 самиів, 12 самок) масою 160-220 г. Експериментальних тварин розподілено на 3 групи по 8 тварин (4 самки, 4 самиі): перша група слугувала для вивчення макро-, друга - для мікро-, третя для ультрамікроскопічної організації тристулкового та двостулкового клапанів серия білого щура. Евтаназію тварин проводили шляхом передозування внутрішньоочеревинного наркозу з використанням тіопенталу натрію (із розрахунку 25 мг/кг маси тіла тварини).

Усіх піддослідних тварин утримували в умовах віварію Львівського начіонального медичного університету імені Данила Галииького. Дослідження проводили відповідно до положень «Європейської конвениії щодо захисту хребетних тварин, яких використовують в експериментальних та інших наукових иілях» (Страсбург, 1986), Директив Ради Європи 86/609/ЕЕС (1986), Закону України № 3447-IV «Про захист тварин від жорстокого поводження», загальних етичних принципів експериментів на тваринах, ухвалених Першим начіональним конгресом України з біоетики (2001).

Зображення з гістологічних препаратів тристулкового та двостулкового клапанів серия на (C) Симівська Р.Р., 2018 
монітор комп'ютера виводили з мікроскопа MICROmed SEO SCAN ma за допомогою відеокамери Vision CCD Camera. Дослідження проводили у визначені терміни досліду в препаратах, забарвлених гематоксилін-еозином. Електронно-мікроскопічне дослідження двостулкового та тристулкового клапанів серия білих щурів проводили на електронному трансмісійному мікроскопі ТЕМ 100. Фотографували за допомогою циифрової камери SONY-19.

Дослідження проведено в рамках виконання фрагменту планової комплексної науково-дослідної роботи «Структурна організаџія, ангіоархітектоніка та антропометричні особливості органів у внутрішньо- та позаутробному періодах розвитку, за умов екзо- та ендопатогенних факторів», № державної реєстрації $0115 U 000041$

Результати дослідження та їх обговорення. Тристулковий клапан білого щура - це система трьох великих стулок трикутної форми, основи яких зливаються. Чітко розрізняються перегородкову, пристінкову (парієтальну) та кутову стулки. Перегородкова стулка відходить від перегородкового краю передсердно-шлуночкового отвору, пристінкова - від каудального краю передсердношлуночкового отвору, а кутова стулка знаходиться в краніальному куті передсердно-шлуночкового отвору, відходить від перегородкової та краніальної поверхонь правого шлуночка. Морфометричний аналіз показав, що довжина перегородкової стулки становить $2,5 \pm 0,5$ мм, ширина 2,0 $\pm 0,3$ мм, пристінкової стулки - відповідно

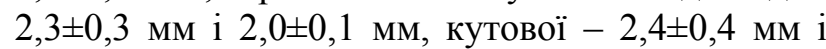
$2,1 \pm 0,1$ мм. Вільний край кожної стулки має вигляд пластинки, яка за допомогою тяжів - сухожилкових струн - прикріплюється до трьох сосочкових м'язів. Сосочкові м'язи мають конічну форму і є продовженням серцевого м'яза.

Двостулковий клапан складається 3 двох стулок. Одна стулка - перегородкова, починається від перегородкового краю лівого передсердношлуночкового отвору, відділяючи його від отвору аорти, що є особливістю білого щура. Довжина їі

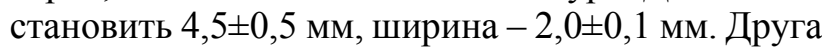
стулка - пристінкова (парієтальна), починається від пристінкового краю передсердно-шлуночко-

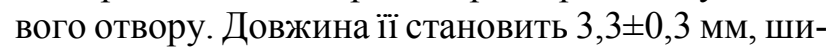
рина $-1,7 \pm 0,1$ мм. Обидві стулки сухожилковими струнами (їх налічується у білого щура 8) прикріплюються до двох сосочкових м'язів.

Гістологічно і правий, і лівий передсердношлуночкові клапани представлені складками ендокарда (рис. 1).

Ендокард дво- і тристулкового клапанів серця білого щура складається 3 3-х шарів:

1) внутрішнього та зовнішнього - ендотеліального - у вигляді пласту плоских полігональної форми, витягнутих у довжину клітин 3 нерівними хвилястими краями. На внутрішній поверхні (оберненій до порожнини шлуночка) клапанів ендотеліальні клітини містять багато мікроворсинок. На зовнішній поверхні клапанів (оберненій до порожнини передсердя) ендотелійні клітини розміщені значно віддалено одна від одної порівняно зі шаром внутрішнього ендотелію;

2) підендотеліального шару, який представлений багатою на фібробласти сполучною тканиною. У складі цієї сполучнотканинної основи виділяють поверхневий волокнистий та глибокий губчастий шари. Поверхневий волокнистий шар це щільна сполучна тканина 3 невеликою кількістю клітин, товстими пучками колагенових волокон, оріснтованих у різних напрямках, що забезпечує міцність за умов дії різноманітних чинників. Пучки колагенових волокон розмежовані тонкими прошарками основної речовини, тілами фіброцитів та поодинокими еластичними волокнами. Тонкі колагенові волокна ендокарду поступово переходять у фіброзну пластинку стулки клапана, а в місці прикріплення дво- і тристулкового клапанів - у фіброзні кільця. Глибокий губчастий шар - це пухка сполучна тканина, багата клітинами;

3) м'язово-еластичний шар представлений гладкими міоцитами, обплетеними пучками колагенових волокон $з$ фібробластами та значною кількістю еластичних волокон.

В основі клапанів ендокард відділений від міокарда сполучнотканинною основою, що містить товсті еластичні, колагенові та ретикулярні волокна. Між ними розміщені кровоносні судини та нерви. Передсердний бік клапанів має гладку поверхню. Шар ендотелію більш виражений та щільніший порівняно зі шлуночковим боком. Шлуночковий бік має нерівну поверхню через вирости, від яких починаються сухожилкові нитки. У цій ділянці під ендотелієм розташовані лише кілька еластичних волокон (рис. 2).

Електронно-мікроскопічне дослідження двота тристулкового клапанів серця білого щура показало, що товщина ендотеліальних клітин неоднакова в різних іiі ділянках; вирізняють: ядерну ділянку (найтовстішу), яка містить ядро ендотеліоцита видовженої (овальної) форми, у клітині одночасно може бути 2-3 ядра і більше; ділянку органел, що містить органели і включення та периферійну ділянку (найтоншу), яка містить отворифенестри (рис. 3). 


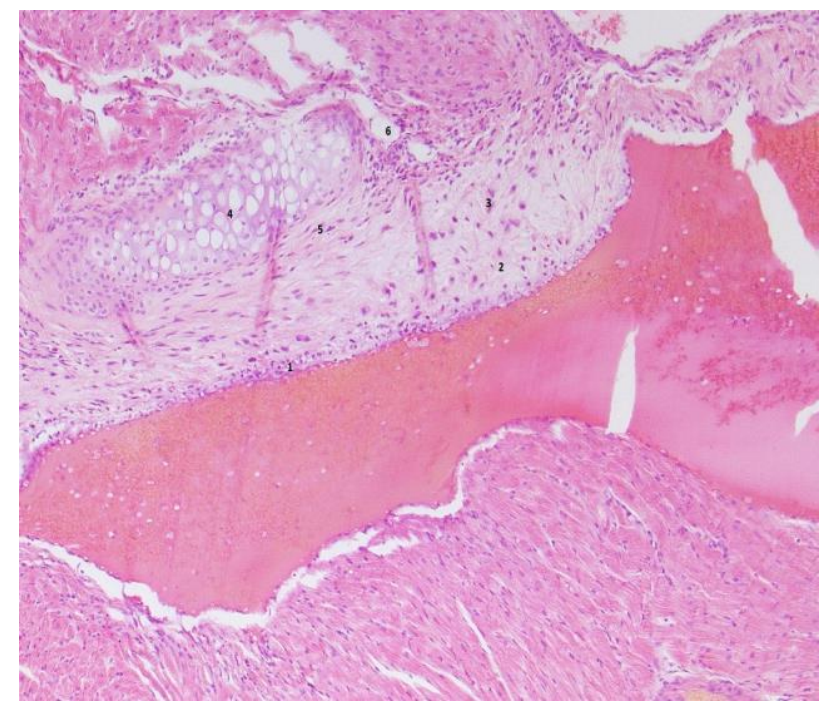

Рис. 1. Ендокард основи тристулкового клапана білого щура. Забарвлення гематоксилін-еозином. Збільшення х200

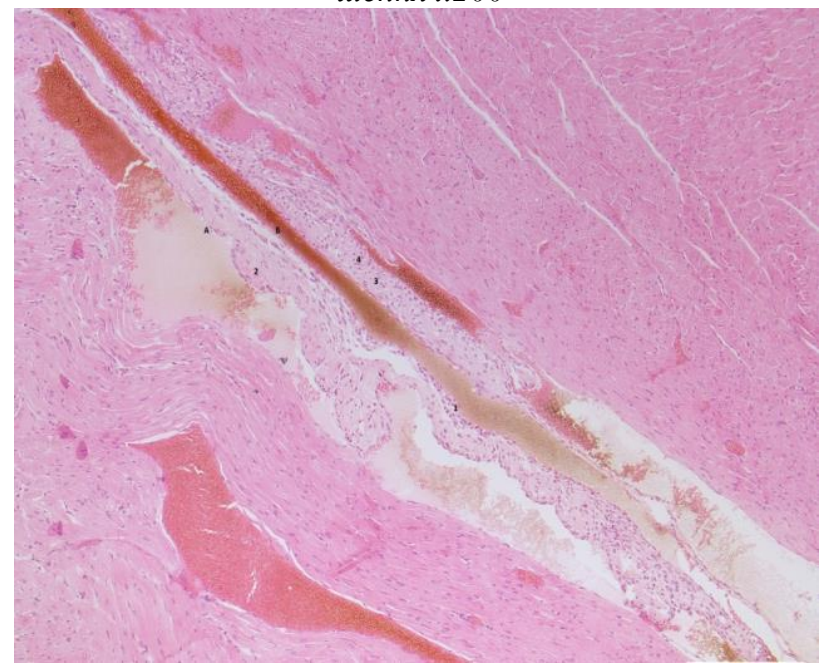

Рис. 2. Стулки лівого передсердно-илуночкового клапана. Забарвлення гематоксилін-еозином. Збільшення $x 200$

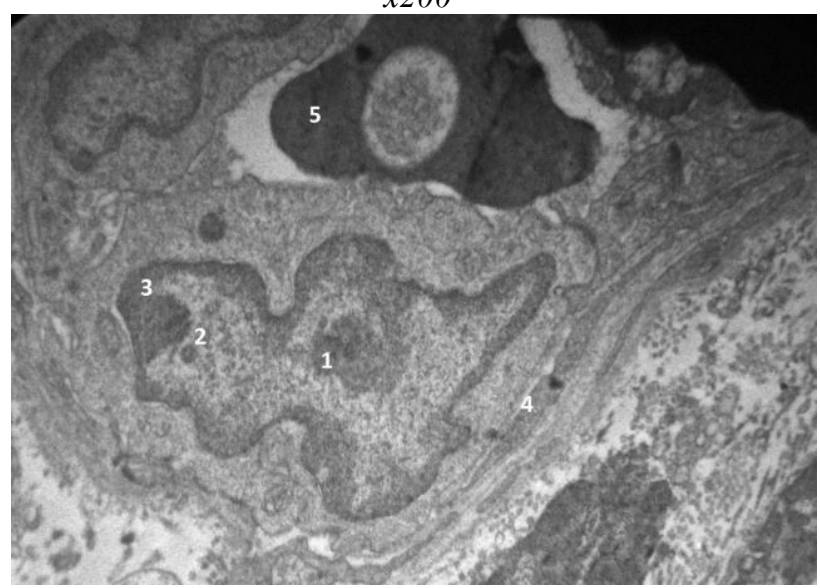

Рис. 3. Ультратонкий зріз артеріоли в основі двостулкового клапана білого щура. Електронна мікрофотографія. 3б.: х4000: 1 -ядро ендотеліоичта; 2 - мітохондрії у ділянщі органел; 3 - периферійна ділянка ендотеліоцита; 4 -базальна мембрана; 5 -еритроцит в просвіті артеріоли
Обернена до току крові поверхня ендотеліоцитів укрита шаром глікопротеїнів. Уздовж внутрішньої і зовнішньої поверхні клітин розташовані піноцитозні пухирці та кавеоли, що засвідчує про активний трансендотеліальний транспорт різних речовин. Ендотеліоцити мають окремі мікроворсинки, а також утворюють клапаноподібні структури, які збільшують поверхню ендотелію і змінюють свої розміри залежно від активності трансендотеліального транспорту. Ендотеліальні клітини зв'язані між собою щільними замикальними контактами. У ділянці такого контакту відбувається максимальне зближення плазматичних мембран сусідніх клітин: кінці інтегральних білків плазмолем сусідніх клітин утворюють міжмолекулярні містки, а наявний проміжок ущільнюється за рахунок йонів кальцію та фібрил, які анастомозують, зовнішні гідрофільні кшари і глікокалікс суміжних плазмолем ніби зливається при цьому в один суцільний шар. Ендотелій розміщується на відносно товстій базальній мембрані, яка має тонкофібрильну будову, містить колаген, глікозаміноглікани та ліпіди. Базальна мембрана забезпечує фіксацію ендотеліальнихї клітин та створює зовнішню опору для цитоскелета. Колагенові волокна побудовані з пучків фібрил, зцементованих глікозаміногліканами та глікопротеїнами. Фібрили складаються з мікрофібрил, що під мікроскопом нагадують хвилясті нитки (рис. 4). Мікрофібрили побудовані з тонших елементів протофібрил, а останні з молекул тропоколагену. Колагенові волокна містять $65 \%$ води. Фібробласти мають вигляд великих клітин 3 відростками.

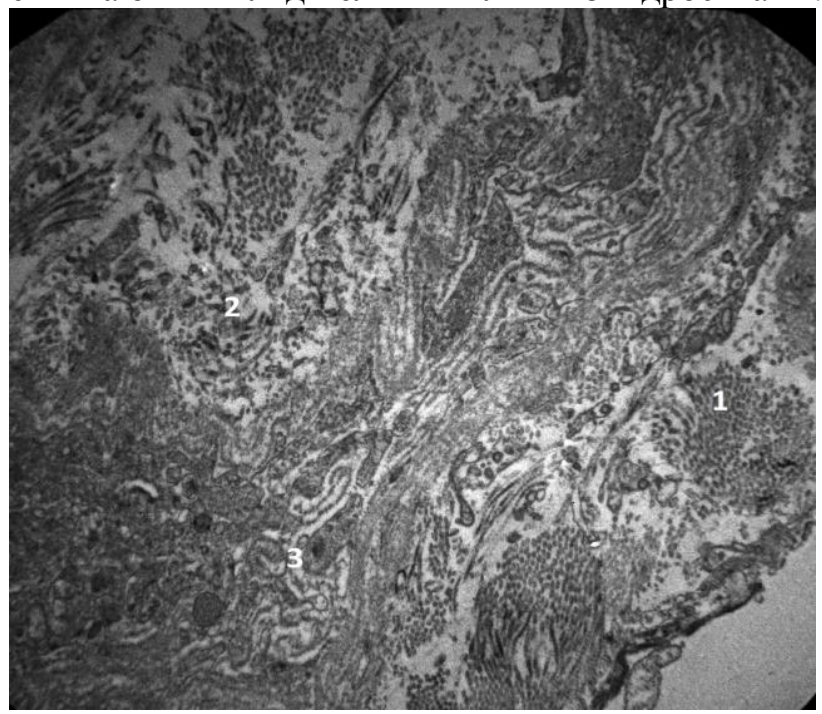

Рис. 4. Сполучнотканинна основа тристулкового клапана серия білого щура. Електронна мікрофотограрія. 3б.: х4000: 1 - поперечно зрізані пучки колагенових фібрил; 2 - еластичне волокно: глікопротеїнові мікрофібрили, щчо оточують еластинову сериевину; 3 - ядро гладком'язової клітини 
Тіло клітини можна поділити на дві зони - центральну ендоплазму, що містить всі органели та периферійну ектоплазму, що зливається 3 міжклітинною речовиною та не має чітких меж. Трапляються також фіброцити (кінцеві форми розвитку фібробластів), які мають веретеноподібну форму 3 невеликою кількістю органел. Еластичні волокна побудовані з еластинових протофібрил, що в комплексі з глікопротеїнами утворюють мікрофібрили. Гладкі міоцити мають вигляд веретеноподібних клітин з відростками. У їх цитоплазмі виявляють тонкі актинові та товсті міозинові міофіламенти. Оболонка кожного міоцита огорнута тонкою базальною мембраною, до якої прикріплюються колагенові фібрили. У базальній мембрані $€$ отвори, в ділянці яких м'язові клітини контактують між собою за допомогою щілинних контаків (нексусів). Навколо м'язових клітин еластичні та тонкі колагенові волокна утворюють сітку - ендомізій, який поєднує сусідні міоцити.

Висновки. 1. Ендокард правого та лівого пе- редсердно-шлуночкових клапанів складається 3 трьох шарів: внутрішнього та зовнішнього - ендотеліального - у вигляді пласту плоских полігональних клітин з нерівними хвилястими краями, підендотеліального шару, який представлений сполучною тканиною, та м'язово-еластичного шару, що містить гладкі міоцити, обплетені пучками колагенових волокон з фібробластами та більшою кількістю еластичних волокон. 2. Електронно-мікроскопічне дослідження дво- та тристулкового клапанів серця показало, що товщина ендотеліальних клітин неоднакова в різних іiі ділянках. Ендотелій розміщується на товстій базальній мембрані. Колагенові волокна побудовані з пучків фібрил, зцементованих глікозамінгліканами та глікопротеїнами. Еластичні волокна формуються 3 еластинових протофібрил, що в комплексі з глікопротеїнами утворюють мікрофібрили.

Перспективи подальших досліджень. Подальше вивченням макро-, мікро-, та ультрамікроскопічної організації клапанного апарату серця.

\section{References}

1. Sikora VZ, Yarmolenko OS. Vikovi osoblyvosti morfofunktsionalnykh peretvoren miokarda $v$ normi ta $v$ umovakh vplyvu ushkodzhuvalnykh chynnykiv (ohliad literatury) [Age features of morphofunctional myocardial transformations in norm and in conditions of influence of damaging factors (literature review)]. Zhurnal klinichnykh ta eksperymentalnykh medychnykh doslidzhen 2013;1(3):263-74. (in Ukrainian).

2. Timofeyev EV, Lobanov MYu, Zemtsovskiy EV. Rasprostranennost malykh anomaliy serdtsa u prakticheski zdorovykh lits molodogo vozrasta [Prevalence of small heart anomalies in practically healthy young people]. Zdorovye, demografiya, ekologiya finno-ugorskikh narodov. 2013;2:47-50. (in Russian).

3. Abdulkareem N, Smelt J, Jahangiri M. Bicuspid aortic valve aortopathy: genetics, pathophysiology and medical therapy. Interact Cardiovasc Thorac Surg. 2013;17(3):554-9.

4. Gorustovich OA. Anatomo-topograficheskiye osobennosti arteriy i elementov klapannogo apparata serdtsa cheloveka [Anatomical and topographical features of the arteries and elements of the valvular apparatus of the human heart] [dissertation abstract]. Minsk; 2017. (in Russian).

5. Popadynets OH, Sahan OV, Dubyna NM. Klapany sertsia liudyny: rozvytok, makro- ta mikroskopichna budova, osoblyvosti krovopostachannia (ohliad literatury) [Human heart valves: development, macroscopic and microscopic structure, features of blood supply (review of literature)]. Bukovynskyi medychnyi visnyk 2014;18(4):212-6. (in Ukrainian).

6. Kovalenko VM, Nesukai OH, Knyshov HV, Vatutin MT, Voronkov LH, Illiash MH, et al. Profilaktyka, diahnostyka ta likuvannia infektsiinoho endokardytu. Rekomendatsii robochoi hrupy z khvorob miokarda, perykarda, endokarda ta klapaniv sertsia Asotsiatsii kardiolohiv Ukrainy [Prevention, diagnosis and treatment of infective endocarditis. Recommendations of the working group on diseases of the myocardium, pericardium, endocardium and heart valves of the Association of Cardiologists of Ukraine]. Ukrainskyi kardiolohichnyi zhurnal. 2015;6:11-24. (in Ukrainian).

7. Akyüz AR, Kul S. Bicuspid aortic valve and extremely elongated chordae tendineae protruding into the left ventricular outflow tract. Anatol J Cardiol. 2015 May 1;15(5):E14-5. doi: 10.5152/akd.2015.6090.

8. Alegret JM, Martínez-Micaelo N, Aragonès G, Beltrán-Debón R. Circulating endothelial microparticles are elevated in bicuspid aortic valve disease and related to aortic dilation. Int J Cardiol. 2016 Aug 15;217:35-41. doi: 10.1016/j.ijcard.2016.04.184.

9. Aivazian KA, Vasylieva VA, Kiriakulov HS. Budova sukhozhylkovykh strun peredserdno-shlunochkovykh klapaniv zvychaino sformovanykh serdets ditei i pry tetrodi Fallo [The structure of the atrial-ventricular tendons of the atherosclerotic valves of the usually formed hearts of children and with the phallot tetrodus]. Halytskyi likarskyi visnyk. 2010; 17(2, part 2):8-10 (in Ukrainian). 
10. Fedoniuk LYa, Penteleichuk NP. Morfolohiia peredserdno-shlunochkovykh klapaniv sertsia u ditei hrudnoho viku ta osoblyvosti budovy sukhozhylkovykh strun v normi [Morphology of the atrial-ventricular heart valves in infants and the features of the structure of the tendon strings are normal]. Visnyk Cherkaskoho universytetu. Seriia: Biolohichni nauky. 2015;2:109-15 (in Ukrainian).

11. Kosharnyi VV, Abdul-Ohly LV, Kozlovska HO, Vykhrystenko KM. Dynamika zminy strukturnykh parametriv klapaniv aorty $i$ lehenevoho stovbura u postnatalnomu ontohenezi [Dynamics of the structural parameters of the aorta and pulmonary valves in postnatal ontogenesis]. Aktualni problemy suchasnoi medytsyny: Visnyk ukrainskoi medychnoi stomatolohichnoi akademii. 2015;3(1):188-194. (in Ukrainian).

12. Miroshnychenko OO, Trykoz VH. Morfolohiia stulok klapaniv sertsia plodiv $i$ ditei rannoho viku [Morphology of the valves of the heart valves of fruits and young children]. Medytsyna tretoho tysiacholittia: Proceedings of the mizhvuzivskoi konferentsii molodykh vchenykh ta studentiv; 2013 Jan 15-16; Kharkiv. Kharkiv: Kharkiv National Medical University; 2013. 43-44 (in Ukrainian).

\section{МАКРО-, МИКРО-, И УЛЬТРАСТРУКТУРНА ОРГАНИЗАЦИЯ ТРЕХСТВОРЧАТОГО И ДВУ- СТВОРЧАТОГО КЛАПАНОВ СЕРДЦА БЕЛОЙ КРЫСЫ}

Резюме. В статье приведены и проанализированы данные исследования, что проводилось на белых крысах самках и самцах репродуктивного возраста. Целью исследования было определить особенности макро-, микро-, и ультраструктурної организации трехстворчатого и двустворчатого клапанов сердца экспериментальных животных. Установлено, что эндокард правого и левого предсердно-желудочковых клапанов состоит из трех слоев: внутреннего и внешнего - эндотелиального - в виде пласта плоских полигональных клеток с неравными волновыми краями, подэндотелиального слоя, который представлен соединительной тканью и мышечно-эластичного слоя, который содержит гладкие миоциты, оплетенные щепотками коллагеновых волокон с фибробластами и большим количеством эластичных волокон. Електронномиркроскопичиские исследования дво- и трехстворчатого клапанов сердца показало, что толщина эндотелиальных клеток неодинакова в разных ее участках. Эндотелий размещается на толстой базальной мембране. Коллагеновые волокна построены из пучков фибрилл, сцементированных гликозамингликанами и гликопротеинами. Эластичные волокна формируются из эластиновых протофибрилл, что в комплексе с гликопротеинами образуют микрофибриллы.

Ключевые слова: структурная организация; трехстворчатый клапан; двустворчатый клапан; белая крыса.

\section{MACRO-, MICRO-, AND ULTRA-STRUCTURAL ORGANIZATION OF TRICUSPID AND BI- VALVE VALVES OF THE WHITE SHARK HEART}

Abstract. Over the past 10 years, cardiovascular disease has become the main cause of mortality in the world and accounts for $30 \%$ of all cases and $45 \%$ of all non-infectious causes of death. Pathology of the cardiovascular system is the most widespread, tends to increase, often leads to disability and mortality of the workingage population and is a medical and social problem. Despite the large number of morphological studies, many questions relating to the valve heart remain unresolved. The valve apparatus of the heart provides normal hemodynamics of the cardiac output and heart biomechanics as a whole. Damage to any of the structural components of the atrioventricular valve leads to the appearance of the pathology of the valve apparatus in general, which may lead to hemodynamic disorders. Current issues concerning the dynamics of the development of valves and their structural components remain, blood supply to the valvular apparatus is normal, as they carry a large functional load. The purpose of the study to establish the features of the macro, micro, and ultrastructural organization of tricuspid and bivalve valves of the white shark heart. Material and methods. The study was performed on 24 sexually mature white rats of reproductive age (12 males, 12 females) weighing 160-220 g. Experimental animals were divided into 3 groups of 8 animals ( 4 females, 4 males): the first group served for the study of macro- , the second for micro, and the third for the ultramicroscopic organization of the tricuspid and bivalve valves of the white rat heart. Euthanasia of animals was performed by overdose of intraperitoneal anesthesia using sodium thiopental ( $25 \mathrm{mg} / \mathrm{kg}$ of body weight of the animal). All experimental animals were kept under the vivarium of the Lviv National Medical University named after Danylo Halytsky. The research was conducted in accordance with the provisions of the European Convention for the Protection of Vertebrate Animals used for Experimental and Other Scientific Purposes (Strasbourg, 1986), Council of Europe Directives 86/609 / EEC (1986), Law of Ukraine No. 3447-IV «On the Protection of Animals from Cruel behavior», the general ethical principles of experiments on animals adopted by the First National Congress of Ukraine on Bioethics (2001). Images from the histological preparations of the tricycle and bivalve valves on the computer monitor were taken from the microscope MICROmed SEO SCAN and using the Vision CCD 
Camera. The studies were carried out at definite dates of the experiment in preparations of stained hematoxylin-eosin. An electron microscopic examination of the bivalve and tricuspid valves of the white rats hearts was carried out on an electronically transmitted TEM-100 transducer microscope. Photos were taken using the digital camera SONY-19. Results and discussion. Tricuspid valve of a white rat heart- a system of three large openers of a triangular shape, the bases of which are merged. The morphometric analysis showed that the length of the septum arch is $\pm 2.5 \mathrm{~mm}$, the width is $\pm 2.0 \mathrm{~mm}$, the poster arm is $\pm 2.3 \mathrm{~mm}$ and $\pm 2.0 \mathrm{~mm}$ respectively, the angle is $\pm 2.4 \mathrm{~mm}$ and $\pm 2.1 \mathrm{~mm}$ (average values). The free edge of each leaf has the shape of a plate, which, with the help of strains - tendon strings, is attached to three papillary muscles. The papilla muscles have a conical shape and are a continuation of the heart muscle. The bivalve valve consists of two doors. One septum, partition, begins with the septum edge of the left atrial-ventricular opening, separating it from the opening of the aorta, which is a feature of the white rat. Its length is $\pm 4.5 \mathrm{~mm}$, width $- \pm 2.0 \mathrm{~mm}$. The second door - parietal (parietal), starts from the wall of the atrium ventricular opening. Its length is $\pm 3,3$ $\mathrm{mm}$, width $- \pm 1,7 \mathrm{~mm}$. Histologically and right, and the left atrioventricular valve are represented by the folds of the endocardium. The endocard of bivalve and tricycle valves of the white rat heart consists of 3 layers: 1) internal and external - endothelial - in the form of a layer of flat polygonal form, elongated in the length of cells with uneven wavy edges. On the inner surface (ventricular vestige), the endothelial cells contain a lot of microvilli; 2) sub-endothelial layer, which is represented by fiber-rich connective tissue. As part of this connective tissue base, the surface fibrous and deep spongy layers are isolated. Surface fibrous layer - a dense connective tissue with a small number of cells, thick bundles of collagen fibers oriented in different directions, which provides strength under the influence of various factors. The deep sponge layer is a loose connective tissue rich in cells; 3 ) the muscular-elastic layer is presented by smooth miocites, braided with bundles of collagen fibers with fibroblasts and more elastic fibers. Electron microscopic examination of two- and threebluestinal valves of the white rat heart showed that the thickness of endothelial cells varies in different parts of it, distinguish: the nuclear zone (the most thick), which contains the core of the endotheliocyte of the elongated (oval) form, the cell can simultaneously be 2-3 nuclei and more; a zone of organelles containing organelles and inclusion and a peripheral zone (thinnest) containing open-fenestria. The endothelium is placed on a relatively thick basal membrane that has a finfibrile structure, contains collagen, glycosaminoglycans and lipids. The basement membrane ensures the fixation of the endothelial cells and creates an external support for the cytoskeleton. Collagen fibers are constructed from fibrillated beams cemented with glycosaminoglycans and glycoproteins. Elastic fibers are constructed of elastin protofibrils, which, in combination with glycoproteins, form microfibrils. Conclusions. As a result of studies on male and female rats, it was found that endocardium of the right and left atrioventricular valves consists of three layers: internal and external - endothelial - in the form of a layer of flat polygonal cells with uneven waved edges, a sub-endothelial layer, which is represented by a connective tissue and a muscular-elastic layer containing smooth myocytes, braided with bundles of collagen fibers with fibroblasts and more elastic fibers. Electron microscopic examination of tricuspid and bivalve heart valves showed that the thickness of endothelial cells varies in different parts of it. The endothelium is placed on a thick basal membrane. Collagen fibers are constructed from fibrillated beams cemented with glycosaminglycans and glycoproteins. Elastic fibers are formed from elastin protofibrils, which, in combination with glycoproteins, form microfibrils.

Key words: structure organization; tricuspid valve; bivalve valve; white rat.

\section{Відомості про автора:}

Симівська Роксолана Романівна - аспірант кафедри нормальної анатомії Львівського національного медичного університету імені Данила Галицького;

Information about author:

Symivska Roksolana R. - Post-graduate student of the department of normal anatomy Danylo Halytsky Lviv National Medical University.

Надійшла 17.09.2018 p. Рецензент - проф. Федонюк Л.Я. (Тернопіль) 